\title{
Mechanisms of cytokine-induced death of cultured bovine luteal cells
}

\author{
M. G. Petroff*, B. K. Petroff ${ }^{\dagger}$ and J. L. Pate \\ Department of Animal Sciences, Ohio State University, OARDC, Wooster, OH 44691, USA
}

\begin{abstract}
Tumour necrosis factor $\alpha$ (TNF- $\alpha$ ) and gamma-interferon (IFN- $\gamma$ ) are cytotoxic to bovine luteal cells in vitro and may contribute to cell death during luteolysis in vivo. In this study, the mechanism by which luteal cells are killed by TNF- $\alpha$ and IFN- $\gamma$ was investigated. Luteal cells were cultured for 7 days in the presence or absence of TNF- $\alpha$ and IFN- $\gamma$. Inhibitors of arachidonate metabolism or scavengers of free radicals were included in the culture media. In addition, the effect of IFN- $\alpha$ on the viability of cytokine-treated luteal cells was tested. Lastly, untreated and cytokine-treated cells were subjected to single cell gel electrophoresis for quantification of DNA fragmentation. Neither indomethacin nor nordihydroguaiaretic acid, which are inhibitors of cyclooxygenase and lipoxygenase, respectively, were able to prevent cytokine-induced cell
\end{abstract}

\section{Introduction}

In many species, luteolysis is the result of pulsatile release of $\mathrm{PGF}_{2 \alpha}$ from the uterus, which initiates a complex cascade of events culminating in a loss of steroidogenesis and cellular apoptosis. Although luteolysis is induced in vivo by exogenous treatment with $\mathrm{PGF}_{2 \alpha}$ the events are not mimicked by treatment of luteal cells with this agent in vitro. Although agonist-stimulated steroidogenesis may be attenuated by $\mathrm{PGF}_{2 \alpha}$ in cultured bovine luteal cells, $\mathrm{PGF}_{2 \alpha}$ is not cytotoxic to these cells; indeed, these cells can be stimulated to produce copious quantities of the prostaglandin without causing cell death (Pate and Condon, 1984; Nothnick and Pate, 1990). Therefore, it is clear that placing luteal cells into a culture system results in the loss of critical cellular and chemical mediators of luteolysis.

As cytokines are both cytotoxic to luteal cells and inhibitory to luteal cell function in vitro (Benyo and Pate, 1992; Jo et al., 1995a), it is possible that these factors contribute to luteolysis. Influx of leucocytes, primarily macrophages, during luteolysis

*Present address: Center for Reproductive Sciences, Department of Anatomy and Cell Biology, University of Kansas Medical Center, 3901 Rainbow Blvd, Kansas City, Kansas 66160, USA

†Present address: Center for Reproductive Sciences, Department of Molecular and Integrative Physiology, University of Kansas Medical Center, 3901 Rainbow Blvd, Kansas City, KS 66160, USA

${ }^{\ddagger}$ Correspondence

Email: pate.1@osu.edu death. Similarly, both the phospholipase $A_{2}$ inhibitor arachidonyltrifluoromethyl ketone and the nitric oxide synthase inhibitor $N^{G}$-monomethyl-L-arginine, were largely without effect. In contrast, while vitamin $\mathrm{C}$ did not significantly affect viability, superoxide dismutase plus catalase increased viability of cytokine-treated cells $(P<0.05)$, and IFN- $\alpha$ prevented cell death $(P<\mathbf{0 . 0 5})$. Finally, while control cells remained free of DNA damage, TNF- $\alpha$ plus IFN- $\gamma$ induced significant amounts of DNA damage by $48 \mathrm{~h}$ after initiation of treatment $(P<0.05)$. In conclusion, reactive oxygen species, but not arachidonate metabolism or nitric oxide, contribute to cytokine-induced luteal cell death in vitro, and the process of cell death may be via apoptosis. Furthermore, IFN- $\alpha$ may confer protective effects against cytokine-induced cell death in bovine luteal cells.

has been documented in corpora lutea of many species (pig: Hehnke et al., 1994; rat: Townson et al., 1996; cow: SpanelBorowski et al., 1997), and their functionality is evident by the presence of cytokines and chemokines (Bagavandoss et al., 1990; Ji et al., 1991; Townson et al., 1996). The mRNAs for tumour necrosis factor $\alpha$ (TNF- $\alpha$ ) and gamma-interferon (IFN$\gamma$ ), cytokines which in combination have profound cytotoxic effects on luteal cells in vitro, are present concomitantly within the corpus luteum, indicating that these cytokines are plausible mediators of cytotoxicity in vivo (Petroff et al., 1999).

There is speculation on the possible subcellular mechanisms by which luteal cell death occurs. For example, Hansel et al. (1991) and Wiltbank et al. (1989) hypothesized that cytotoxicity of luteal cells in vivo results from a sustained increase in intracellular calcium concentrations in response to $\mathrm{PGF}_{2 \alpha}$. Antioxidants such as vitamin $\mathrm{C}$ are depleted from the corpus luteum during luteolysis; this may increase the susceptibility of the cells to damage inflicted by reactive oxygen species and promote cellular damage (Aten et al., 1992; Endo et al., 1993; Petroff et al., 1998; Tsai and Wiltbank, 1998). Nitric oxide, which is produced by luteal cells of rats, also causes cell death in various target cells, and may have a role in functional luteolysis (Olson et al., 1996). The aim of the present study was to examine possible mechanisms by which TNF- $\alpha$ and IFN- $\gamma$ are cytotoxic to luteal cells using an in vitro model. The mechanism by which luteal cytotoxicity is induced by these cytokines was hypothesized to be the result of one, or a combination of, the mechanisms described above. 


\section{Materials and Methods}

\section{Animals}

Corpora lutea were removed by transvaginal enucleation from nonlactating dairy cows between day 8 and day 12 of the oestrous cycle (day $0=$ day of standing oestrus). Blood samples were collected from the caudal vein immediately before lutectomy for determination of plasma progesterone concentrations. Animals were housed and treated in compliance with the Agricultural Animal Care and Use Committee of Ohio State University.

\section{Luteal cell dissociation and culture}

Corpora lutea were placed immediately in cold medium (Ham's F-12 medium containing $21 \mathrm{mmol}$ sodium bicarbonate $\mathrm{I}^{-1}, 24 \mathrm{mmol} \quad \mathrm{N}$-2-hydroxyethylpiperazine- $\mathrm{N}^{\prime}-2$ ethane sulphonic acid (Hepes) $\mathrm{I}^{-1}$ and $20 \mu \mathrm{g}$ gentamicin $\mathrm{ml}^{-1}$; Fisher Scientific, Pittsburgh) for transport to the laboratory. The corpora lutea were minced and subsequently dissociated with type I collagenase (2000 $\mathrm{Ug}^{-1}$ tissue; Worthington Biochemical, Freehold) in medium containing $0.5 \%$ (w/v) BSA (Sigma, St Louis, MO), as described by Pate and Condon (1982). Viable cells were counted on a haemocytometer using trypan blue exclusion. Polystyrene 24-well culture plates were precoated with Ham's F-12 medium containing 10\% (v/v) bovine calf serum (Life Technologies, Grand Island) at $37^{\circ} \mathrm{C}$ for at least $1 \mathrm{~h}$, then rinsed with $500 \mu \mathrm{l}$ serum-free medium. Cells were plated at a density of $2 \times 10^{5}$ cells per well in Ham's F-12 medium ( $1 \mathrm{ml}$ final volume) containing $20 \mathrm{ng}$ gentamicin $\mathrm{ml}^{-1}, \quad \mathrm{LH} \quad\left(10 \mathrm{ng} \mathrm{ml}^{-1}\right)$, insulin $\left(5 \mu \mathrm{g} \mathrm{m}^{-1}\right)$, selenium $\left(5 \mathrm{ng} \mathrm{ml}^{-1}\right)$ and transferrin $\left(5 \mu \mathrm{g} \mathrm{ml}^{-1}\right)$ (Collaborative Research, Bedford). Luteal cells were cultured at $37^{\circ} \mathrm{C}$ in $5 \% \mathrm{CO}_{2}$ and $95 \%$ oxygen for 7 days. After allowing the cells to attach to the cell culture plates overnight, the cells were washed free of dead or unattached cells and supplied with fresh medium. Treatment of the cells was initiated on day 1 of culture (day $0=$ day of seeding) and was repeated after replenishment of medium on days 3 and 5 . The luteal cell conditioned media were collected and stored at $-20^{\circ} \mathrm{C}$ until assayed for PGF $2 \alpha$. Adherent cells were counted using a $25 \mathrm{~mm}^{2}$ ocular micrometer grid on day 7 of culture. As only viable cells remain attached to the culture plate, the number of cells remaining attached to the culture surface reflects the extent of cytotoxicity.

The effects of various inhibitors of arachidonate metabolism on cytokine-mediated cell death were tested. Cultured luteal cells were treated with recombinant murine TNF- $\alpha$ (50 ng ml ${ }^{-1}$; Gibco, Grand Island, NY), recombinant bovine IFN- $\gamma\left(100 \cup \mathrm{ml}^{-1}\right.$; Ciba-Geigy, Basel) and either nordihydroguaiaretic acid (NDGA) (10 $\mathrm{ng} \mathrm{ml}^{-1} ; n=9$; Sigma) or indomethacin (INDO; $10 \mu \mathrm{g} \mathrm{ml}^{-1} ; n=4$; Sigma), which are inhibitors of the lipooxygenase and cyclooxygenase pathways, respectively. Cytokine-treated luteal cells were also treated with both of these agents $(n=6)$. The effective inhibitory concentrations of these compounds were determined previously in our laboratory. Cytokine- treated cells were treated with arachidonyltrifluoromethyl ketone $\left(\mathrm{AACOCF}_{3} ; 10-1000 \mathrm{ng} \mathrm{ml}^{-1}\right.$; Calbiochem, La Jolla, $\mathrm{CA} ; n=3)$, a competitive inhibitor of the $85 \mathrm{kDa}$ cytosolic phospholipase $\mathrm{A}_{2}\left(\mathrm{PLA}_{2}\right)$ (Bartoli et al., 1994), to examine the effects of $\mathrm{PLA}_{2}$ on cytokine-induced cell death. In addition, luteal cells in the presence or absence of TNF- $\alpha$ plus IFN- $\gamma$ were treated with the nitric oxide synthase inhibitor, $N^{G}$-monomethyl-L-arginine (L-NMMA, $25 \mu \mathrm{mol} \mathrm{I}^{-1}$; Calbiochem; $n=10$ ) or the inhibitors of cellular oxidation, superoxide dismutase plus catalase $(0-1000 \mathrm{U}$ of each per $\mathrm{ml}$; Calbiochem; $n=3)$ and vitamin C (0-100 $\mu \mathrm{g} \mathrm{ml}^{-1}$; Sigma; $n=3$ ). Finally, as IFN- $\alpha$ inhibits TNF- $\alpha$ plus IFN- $\gamma$ stimulated $\mathrm{PGF}_{2 \alpha}$ and major histocompatibility complex (MHC) class II expression on luteal cells (Benyo and Pate, 1992; Pate, 1995), the possibility that this cytokine attenuates TNF- $\alpha$ plus IFN- $\gamma$-mediated cell death was tested using recombinant bovine IFN- $\alpha\left(100 \cup \mathrm{ml}^{-1}\right.$; Ciba-Geigy; $n=5)$.

\section{Nitrate assay}

Media from untreated or TNF- $\alpha$ - and IFN- $\gamma$-treated luteal cells were collected on days 3,5 and 7 of culture and assayed for the presence of nitrite, the stable metabolite of nitric oxide, as described by Green et al. (1982). In brief, 50 $\mu \mathrm{l}$ of $1 \%(\mathrm{w} / \mathrm{v})$ sulphanilic acid in $5 \%(\mathrm{v} / \mathrm{v}) \mathrm{H}_{3} \mathrm{PO}_{4}, 50 \mu \mathrm{l}$ of $0.1 \%(\mathrm{w} / \mathrm{v}) \mathrm{N}$-(1-naphthyl)ethylenediamine dihydrochloride (Sigma) and $50 \mu \mathrm{l}$ luteal cell culture supernatant were combined in microtitre plates. A standard curve was generated using $\mathrm{NaNO}_{2}$ (Sigma), and ranged from 8 to $128 \mu \mathrm{mol} \mathrm{I}^{-1}$. Plates were read immediately on a microtitre plate spectrophotometer (Biotek Instruments, Winooski, VT) at $600 \mathrm{~nm}$. Biological positive controls, which consisted of supernatant obtained from the murine monocyte cell line, RAW 264.7 (American Type Culture Collection, Bethesda, MD) were included in each assay. These cells were cultured in the presence or absence of $100 \cup$ recombinant murine IFN- $\boldsymbol{\gamma}$ (Gibco) $\mathrm{ml}^{-1}$ or IFN- $\boldsymbol{\gamma}$ plus L-NMAA as described by Stuehr and Marletta (1987).

\section{Single cell gel electrophoresis}

Single cell gel electrophoresis was performed for detection of DNA fragmentation in individual cells as described by Green et al. (1996). Corpora lutea were dissociated and cultured in the presence or absence of TNF- $\alpha$ and IFN- $\gamma$ $(n=3)$. On days 3,5 and 7 of culture, cells in triplicate wells were removed from the culture dish and were resuspended in $1 \%(\mathrm{w} / \mathrm{v})$ low melting point agarose (BioRad, Hercules, CA). Cells $(85 \mu \mathrm{l})$ were placed onto a slide that was pre-coated with a layer of $1 \%(\mathrm{w} / \mathrm{v})$ normal agarose and the layer of agarose-embedded cells was sandwiched by a third layer of agarose. The slides were submerged in a lysis buffer (1\% (v/v) Triton X-100, $2.5 \mathrm{~mol}$ $\mathrm{NaCl} \mathrm{I}^{-1}, 100 \mathrm{mmol}^{\mathrm{EDTA}} \mathrm{I}^{-1}, 10 \mathrm{mmol}$ Tris $\mathrm{I}^{-1}, 10 \%(\mathrm{v} / \mathrm{v})$ DMSO; $\mathrm{pH} 10$ ) and incubated in the dark for $1 \mathrm{~h}$ at $4{ }^{\circ} \mathrm{C}$. The slides were placed subsequently in a horizontal electrophoresis unit containing buffer $\left(1 \mathrm{mmol}\right.$ EDTA ${ }^{-1}, 300$ 
Table 1. Effects of metabolic inhibitors on cytokine-induced luteal cell death in cultured bovine luteal cells

\begin{tabular}{|c|c|c|c|c|}
\hline Inhibitor & Control & Inhibitor & TNF- $\alpha+$ IFN- $\gamma$ & TNF- $\alpha+$ IFN- $\gamma+$ inhibitor \\
\hline \multicolumn{5}{|l|}{ Arachidonate inhibitors } \\
\hline $\mathrm{INDO}^{*}\left(10 \mu \mathrm{g} \mathrm{m}^{-1}\right)$ & $69.5 \pm 8.4^{\mathrm{a}}$ & $53.0 \pm 9.4^{b}$ & $33.8 \pm 4.2^{c}$ & $29.8 \pm 6.7^{c}$ \\
\hline NDGA (10 $\left.\mathrm{ng} \mathrm{ml}^{-1}\right)$ & $83.0 \pm 11.0^{\mathrm{a}}$ & $73.1 \pm 10.1^{\mathrm{ab}}$ & $42.3 \pm 7.2^{b}$ & $55.3 \pm 12.6^{b}$ \\
\hline INDO + NDGA* & $62.7 \pm 6.9^{a}$ & $50.3 \pm 6.4^{b}$ & $28.8 \pm 4.4^{\mathrm{c}}$ & $29.2 \pm 6.9^{c}$ \\
\hline $\mathrm{AACOCF}_{3}\left(10 \mathrm{ng} \mathrm{ml}^{-1}\right)$ & $47.9 \pm 11.5^{a}$ & $45.2 \pm 9.3^{\mathrm{a}}$ & $21.9 \pm 8.9^{\mathrm{b}}$ & $26.8 \pm 11.2^{\mathrm{c}}$ \\
\hline \multicolumn{5}{|l|}{ Oxidation inhibitors } \\
\hline SOD/Cat (1000 U ml-1 of each) & $75.8 \pm 5.1^{\mathrm{a}}$ & $74.3 \pm 4.2^{\mathrm{a}}$ & $29.2 \pm 2.0^{b}$ & $46.3 \pm 5.1^{\mathrm{c}}$ \\
\hline Vitamin C (100 $\left.\mathrm{ng} \mathrm{ml}^{-1}\right)$ & $77.0 \pm 3.6$ & $69.8 \pm 2.2$ & $37.2 \pm 2.9$ & $47.7 \pm 6.5$ \\
\hline L-NMMA $\left(25 \mu \mathrm{mol} \mathrm{I}^{-1}\right)$ & $85.8 \pm 10.3^{a}$ & $78.5 \pm 5.7^{\mathrm{a}}$ & $40.9 \pm 5.2^{b}$ & $51.5 \pm 11.2^{b}$ \\
\hline
\end{tabular}

Values are expressed as mean \pm SEM number of cells per $0.25 \mathrm{~mm}^{2}$. The results of experiments using one representative concentration of each inhibitor are shown.

TNF: tumour necrosis factor; IFN: interferon; INDO: indomethacin; NDGA: nordihydroguaiaretic acid; AACOCF $_{3}$ : arachidonyltrifluoromethyl ketone; SOD/Cat: superoxide dismutase/catalase; L-NMMA: $N^{\omega}{ }^{\omega}$-monomethyl-L-arginine.

abc Values within rows with different superscripts are significantly different $(P<0.05)$.

*Adapted from Pate and Townson (1994).

mmol $\mathrm{NaOH}{ }^{-1}$ ), and equilibrated for $40 \mathrm{~min}$ at room temperature before electrophoresis. Electrophoresis was carried out for $24 \mathrm{~min}$ at $22 \mathrm{~V} / 350 \mathrm{~mA}$. Finally, the slides were rinsed twice in neutralization buffer $\left(0.4\right.$ mol Tris $\mathrm{I}^{-1}$, $\mathrm{pH}$ 7.5) and stained with $20 \mu \mathrm{g}$ ethidium bromide $\mathrm{ml}^{-1}$.

Observations were made using an Olympus ET10 microscope at $\times 400$ magnification. Nuclei with extensive DNA damage that are subjected to single cell gel electrophoresis take on the appearance of comets because the fragmented pieces of DNA migrate away from the nucleus, forming the 'tail' of the comet. In contrast, intact DNA remains within the nucleus, which appears as the 'head' of the comet. Thus, the observed structures are referred to as comets hereafter. Quantitative image analysis was obtained using Image-Pro 3 software, and for each replicate, 20 randomly selected comets from each treatment were analysed blindly with respect to treatment. Overlapping comets were excluded from analysis. Migration of DNA was quantified by obtaining a thick band profile with respect to the horizontal axis of the comet, in which average pixel intensity was calculated across the width (vertical axis) of each comet. Line profile histograms were plotted according to distance from the leading edge of the comet head on the abscissa versus pixel intensity on the ordinate. Percentage of total comet DNA constrained within the comet head was determined by encircling the head and excluding all regions from the line profile outside the head. For example, in nuclei containing little or no DNA damage, comet head DNA would include $90-100 \%$ of total DNA, whereas comet heads in which extensive damage had occurred may contain as low as $10 \%$ of total DNA, the remainder being in the tail of the comet. This method allows for the analysis of the degree of DNA fragmentation in individual cells within a cell population, and for precise determination of the proportion of cells within the population with fragmentation.

\section{Radioimmunoassay}

Accumulation of $\mathrm{PGF}_{2 \alpha}$ in cell culture media was assessed by radioimmunoassay as validated for this laboratory (Fairchild and Pate, 1991). Anti-PGF $2 \alpha-$ keyhole limpet haemocyanin antibody was donated by R. Fertel (Ohio State University, Columbus, $\mathrm{OH}$ ).

\section{Statistical analysis}

Cell viability and $\mathrm{PGF}_{2 \alpha}$ data were analysed by two-way ANOVA, blocked on animal, followed by the StudentNewman-Keuls multiple comparisons test. Cells subjected to single cell gel electrophoresis were categorized according to percentage groups, and mean numbers of treated and untreated cells within each percentage group were compared by two-tailed paired $t$ tests. Differences for all analyses were considered significant at $P<0.05$.

\section{Results}

\section{Nitric oxide and luteal cell death}

As expected, treatment of luteal cells with TNF- $\alpha$ and IFN- $\gamma$ resulted in a significant loss in cell viability compared with untreated control cells. The nitric oxide synthase inhibitor, L-NMMA, did not affect the viability of the cells when used alone, and did not prevent cytokine-induced cell death (Table 1). In accordance with these results, concentrations of the stable metabolite of nitric oxide, nitrite, were undetectable in the media of both untreated and TNF- $\alpha$ plus IFN- $\gamma$-treated cells (data not shown).

\section{Arachidonic acid metabolism and luteal cell death}

In this experiment, the hypothesis that activation of the arachidonate metabolic pathway contributed to cytokineinduced cell death was investigated. Cytokine-treated luteal 
cells were incubated in the presence or absence of INDO, NDGA, or both. Neither of these agents was able to inhibit cytokine-induced cell death (Table 1). Similarly, when NDGA and INDO were combined, cell death was not prevented.

The hypothesis that $\mathrm{PLA}_{2}$ activation mediates cytokineinduced luteal cell death was tested by incubation of cytokine-treated luteal cells with $\mathrm{PLA}_{2}$ inhibitor $\mathrm{AACOCF}_{3}$. Concentrations of up to $1 \mu \mathrm{g} \mathrm{ml}^{-1}$ of this inhibitor were not cytotoxic to luteal cells (Table 1). At the lowest concentration used $\left(10 \mathrm{ng} \mathrm{m}^{-1}\right), \mathrm{AACOC}_{3}$ had a slight inhibitory effect on cytokine-mediated cytotoxicity $(P<0.05)$, but higher concentrations of the inhibitor were no more effective (data not shown).

\section{Effects of antioxidants on cytokine-treated luteal cells}

Vitamin $\mathrm{C}$ or superoxide dismutase/catalase was added to TNF- $\alpha+$ IFN- $\gamma$-treated cells to investigate whether scavengers of reactive oxygen species would inhibit cytokine-induced cell death. Neither superoxide dismutase/catalase nor vitamin C was cytotoxic at the concentrations tested (Table 1). Although the lowest concentrations of superoxide dismutase/catalase were ineffective in inhibition of cytokineinduced cell death (data not shown), at $1000 \mathrm{U} \mathrm{ml}^{-1}$ the free radical inhibitors were effective in partially inhibiting cell death (Table $1 ; P<0.05$ ).

\section{Effect of IFN- $\alpha$ on cytokine-treated luteal cells}

As IFN- $\alpha$ can inhibit the ability of TNF- $\alpha$ plus IFN- $\gamma$ to induce MHC molecule expression and stimulate prostaglandin production in luteal cells, the postulate that this cytokine would inhibit TNF- $\alpha$ plus IFN- $\gamma$-induced cytolysis was examined. IFN- $\alpha$ was able to inhibit the cytotoxic effects of TNF- $\alpha$ plus IFN- $\gamma$ on cultured luteal cells (Fig. 1a). As expected, IFN- $\alpha$ also attenuated cytokine stimulation of $\mathrm{PGF}_{2 \alpha}$ production by luteal cells (Fig. 1b).

\section{DNA fragmentation}

Cytokines are known to induce fragmentation of nuclear DNA characteristic of apoptosis in a variety of cell types; therefore, the hypothesis that TNF- $\alpha$ and IFN- $\gamma$ induced DNA fragmentation in luteal cells was tested. Luteal cells cultured in the presence or absence of TNF- $\alpha$ plus IFN- $\gamma$ were harvested, subjected to electrophoresis and stained to examine the degree of DNA fragmentation on days 3, 5 and 7 of culture. Representative comets are shown (Fig. 2a-c). With this procedure, it was possible to analyse the extent to which DNA fragmentation occurred in individual cells in response to treatments. Cells sustaining little DNA damage (Fig. 2a) are represented by comets with large, vividly stained heads; the nuclear DNA clearly remains intact. These comets were typical of those observed for all treatments on day 3 of culture and of the control cells throughout culture. Cells experiencing intermediate and large amounts of DNA damage are shown (Fig. 2b and 2c,
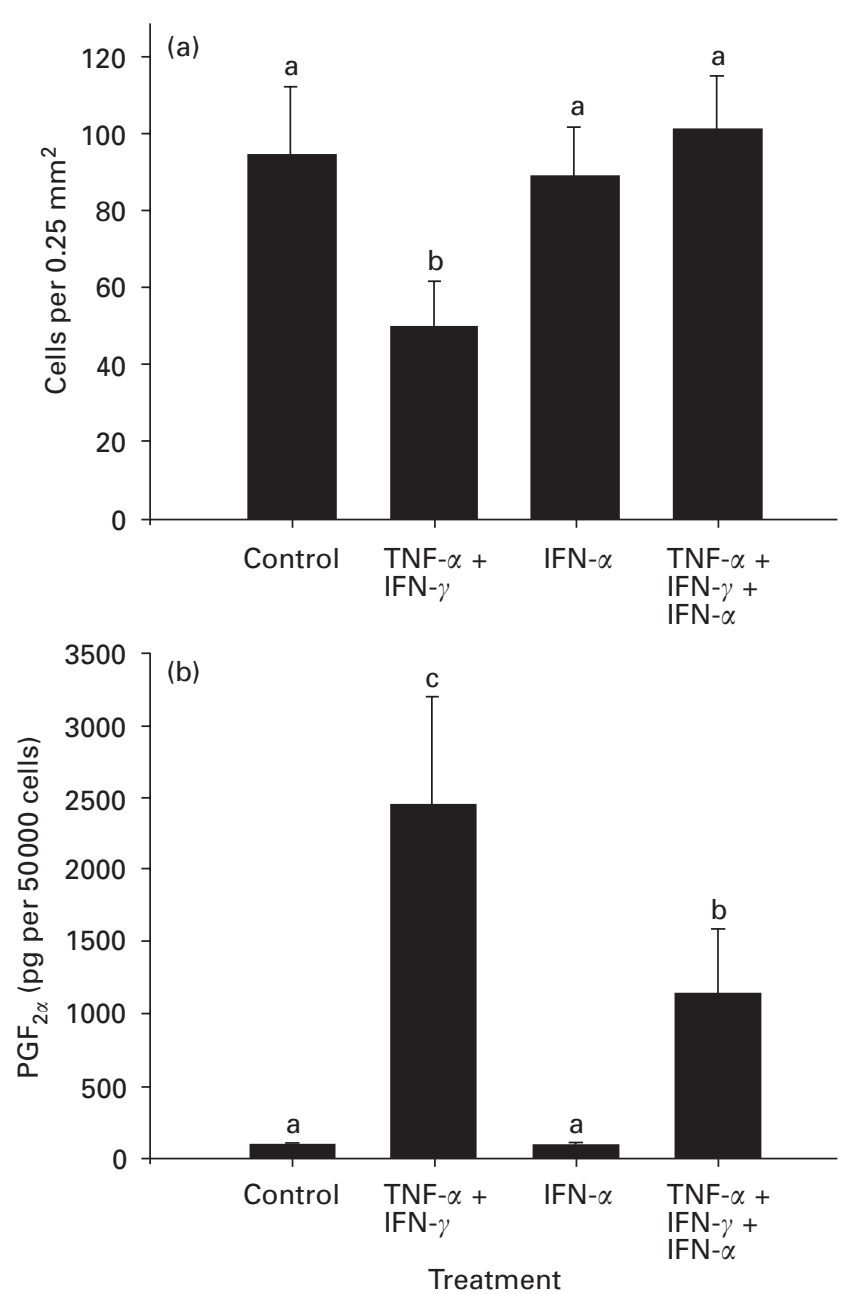

Fig. 1. Effect of interferon $\alpha$ (IFN- $\alpha$ ) on cytokine-induced cell death and $\mathrm{PGF}_{2 \alpha}$ production in cultured bovine luteal cells. (a) Data are presented as mean number of cells per $0.25 \mathrm{~mm}^{2}(n=5)$ or (b) $\mathrm{PGF}_{2 \alpha}$ production per 50000 cells $(n=5)$. abc Different superscripts indicate significant differences among values $(P<0.05)$. TNF: tumour necrosis factor.

respectively); these comets show progressively lower amounts of undamaged nuclear DNA remaining in the head regions with corresponding increases in fragmented DNA in the tail, and are typical of those resulting from cytokinetreated cells.

On day 3 of culture, most of both control and cytokinetreated cells had only a minor degree of DNA fragmentation (Fig. 3). However, although a significant difference in viability was not evident at this early stage of culture as assessed by counting the cells using an ocular micrometer (data not shown), significantly fewer cytokine-treated cells had $80-100 \%$ of the DNA remaining in the head (Fig. 3a). On later days of culture (days 5 and 7), very few cytokinetreated cells with minimal DNA damage were present. In these cultures, increasing numbers of cells with $<50 \%$ of the DNA remaining in the comet head were observed. In 

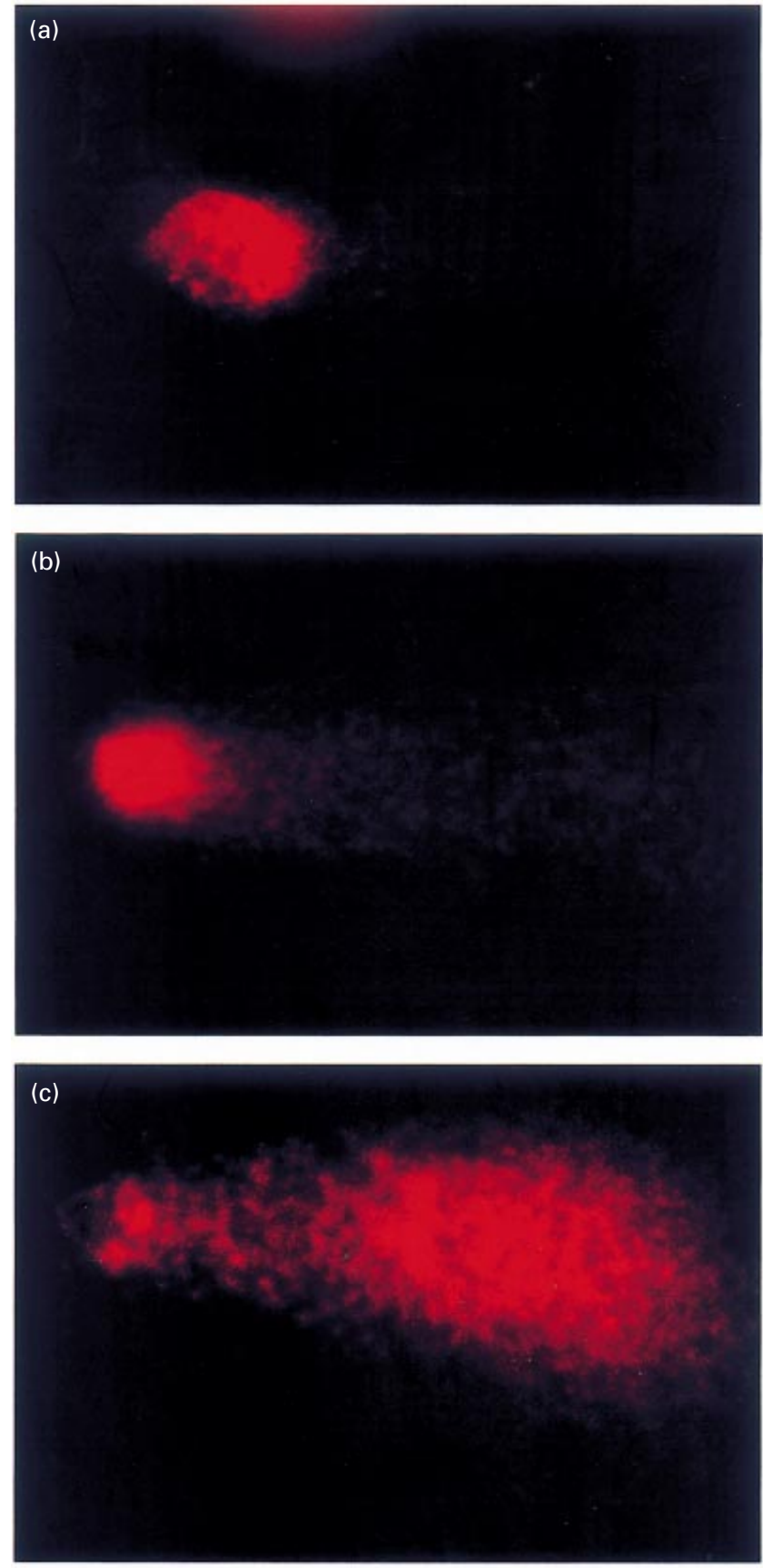

Fig. 2. Comet formation in control and cytokine-treated cultured bovine luteal cells. Three comets are represented with (a) $92.7 \%$ (control, untreated), (b) 68.5\% (cytokine-treated) and (c) $6.8 \%$ (cytokine-treated) of the total DNA visualized remaining in the head region.

contrast, most control cells remained relatively free of DNA damage throughout the 7 days of culture (Fig. 3b,c).

\section{Discussion}

The loss in structural integrity of the corpus luteum during luteolysis entails a breakdown of the extracellular matrix,
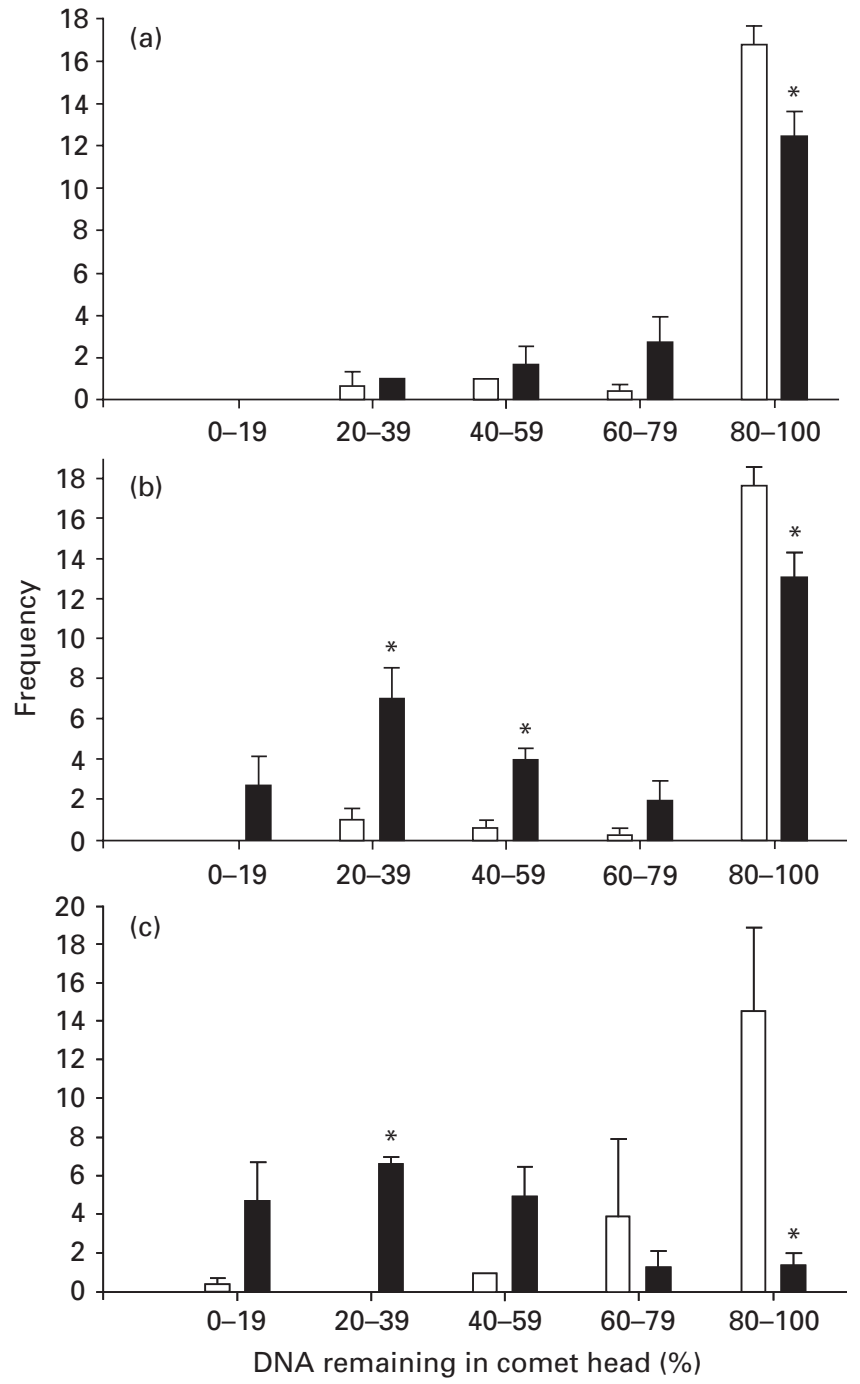

Fig. 3. DNA fragmentation in response to tumour necrosis factor $\alpha$ (TNF- $\alpha$ ) plus interferon $\gamma($ IFN- $\gamma$ ). Data are expressed in histogram formation and are grouped arbitrarily according to the percentage of visualizable DNA remaining in the head region of the comets on days (a) 3, (b) 5 and (c) 7 of culture. The lower the percentage of DNA remaining in the head region, the greater the degree of DNA fragmentation. $\square$ : Control cells; $\mathbf{\square}$ : cytokine-treated cells. *Indicates differences between control and cytokine-treated cells within a percentage group $(n=3 ; P<0.05)$.

vascular demise and cellular apoptosis. The intracellular inducers of apoptosis are diverse in various cell types. In the corpus luteum, accumulation of reactive oxygen species, sustained concentrations of calcium and toxic concentrations of nitric oxide have all been implicated in the initiation of cell death (Hansel et al., 1991; Rueda et al., 1995; Olson et al., 1996). As TNF- $\alpha$ and IFN- $\gamma$ are cytotoxic to luteal cells in vitro, it has been suggested that these cytokines mediate cytotoxic effects in vivo (Pate, 1995). Furthermore, these cytokines are known to initiate apoptosis in other cell types by the mechanisms mentioned above. The results of the present study reveal that treatment of luteal cells with 
cytokines results in DNA fragmentation, which is indicative of apoptosis, and that reactive oxygen species, but not nitric oxide, $\mathrm{PLA}_{2}$ activation or arachidonate metabolism, may be at least partially responsible for their cytotoxic effect. The results of the present study also show that IFN- $\alpha$ exerts a protective effect against cytokine-induced cytolysis of luteal cells in vitro.

The demonstration that TNF- $\alpha$ and IFN- $\gamma$ cause DNA fragmentation in luteal cells in vitro lends support to the hypothesis that these cells undergo apoptosis when treated with cytokines. These results are corroborated by those of Jo et al. (1995a), who showed that cytokine-treated murine luteal cells take on the morphological characteristics of apoptotic cells. The observation that DNA fragmentation is apparent on day 3 of culture indicates that the process of cell death may be underway by day 3 of culture ( $48 \mathrm{~h}$ after initiation of cytokine treatment), before cytotoxic effects are recognized by microscopic examination (Fairchild and Pate, 1991). These results agree with the typical time course required for cell death to occur in response to cytokines in other model systems.

In some cell types, antioxidants and free radical scavengers can inhibit TNF- $\alpha$-induced cell death (Heller and Kronke, 1994). The results of the present study support a role for reactive oxygen species in luteal cell death, as the free radical scavengers superoxide dismutase and catalase partially inhibited cytokine-induced cell death. When superoxide is degraded, hydrogen peroxide is produced, so superoxide dismutase and catalase were combined in the present study to decrease both superoxide anions and hydrogen peroxide. Therefore, while it may be concluded that reactive oxygen species may be involved in cytokineinduced luteal cell death, it is not possible from this study to determine whether superoxide, hydrogen peroxide or a combination mediate cytokine action. Depletion of antioxidants may be important in sensitizing luteal cells to oxidative damage during luteolysis or during cytokine treatment in vitro. Vitamin C, superoxide dismutase activity and catalase activity are depleted from the corpus luteum during luteolysis (Petroff et al., 1998; Rapoport et al., 1998), and the mRNA content for antioxidant enzymes declines during luteolysis (Rueda et al., 1995). Furthermore, vitamin C, which is the most abundant antioxidant in the corpus luteum, is depleted by placing luteal cells in culture (Musicki et al., 1996). Therefore, these conditions probably predispose luteal cells to oxidative damage during luteolysis in vivo, and perhaps during cytokine treatment in vitro. Whether the oxidative damage that occurs during luteolysis is mediated by cytokines remains to be investigated.

The results of the present study lend little support for a role of the activation of arachidonate metabolism in cytokine-induced luteal cell death. Although the lowest concentration of the $\mathrm{PLA}_{2}$ inhibitor $\mathrm{AACOCF}_{3}$ may have inhibited cytotoxicity slightly, the inhibitor was not effective consistently among all animals studied, and higher concentrations of the agent had no effect. The results obtained with INDO treatment are consistent with those of
Fairchild and Pate (1991), who showed that indomethacin did not prevent the modest cytotoxicity of luteal cells caused by IFN- $\gamma$. However, these results are in contrast to reports in which $\mathrm{PLA}_{2}$, lipoxygenase, and cyclooxygenase inhibitors completely block TNF- $\alpha$-induced cell death in other cell types (Kettelhut et al., 1987; Neale et al., 1988; Rabinovitch et al., 1990; Suffys et al., 1991). It is thought that TNF- $\alpha$-mediated cell killing in other cells is caused by leakage of reactive oxygen species as a result of mitochondrial damage or activation of cyclooxygenase and lipoxygenase (Matthews et al., 1987; Rabinovitch et al., 1992; Schulze-Osthoff et al., 1992). In recent experiments, it has been demonstrated that luteal prostaglandin and leukotriene production are increased during luteolysis, and that the mRNA for prostaglandin $\mathrm{G} / \mathrm{H}$ synthase is increased (Blair et al., 1997; Tsai and Wiltbank, 1998). These observations have prompted a hypothesis that intraluteal amplification of prostaglandin synthesis has a role in luteolysis. However, it seems that activation of these pathways alone is not sufficient for cell death, despite a possible role in contributing to release of reactive oxygen species (Sawada and Carlson, 1991).

Some cell types are resistant to the cytolytic actions of TNF- $\alpha$, whereas others are sensitive, and reactive oxygen species seem to play an integral role in TNF- $\alpha$-induced cytotoxicity in TNF-sensitive cells. In fact, a primary mechanism of cellular defence that TNF-resistant cells are endowed with is the stimulation of manganese superoxide dismutase (MnSOD) production. Inhibition of MnSOD activity renders resistant cells susceptible to actions of TNF (Wong and Goeddel, 1988; Wong et al., 1989). As TNF- $\alpha$ alone is not cytotoxic to luteal cells, these cells may be considered TNF-resistant, perhaps because of stimulation of MnSOD by TNF- $\alpha$. Indeed, it has been shown that MnSOD mRNA content is increased in rat luteal cells treated with TNF- $\alpha$ (Sugino et al., 1998a). Alternatively, the luteotrophic hormones prolactin and placental lactogen also increase amounts of mRNA for MnSOD in these cells (Sugino et al., 1998b). Therefore, it is possible that the LH present in the culture medium in the present study also maintained amounts of mRNA for MnSOD, thus inhibiting TNF- $\alpha$ induced cell death. In contrast, IFN- $\gamma$ alone is slightly cytotoxic to luteal cells, and may render TNF- $\alpha$-treated luteal cells susceptible to the cytokine. The mechanism by which this may occur is not clear, but IFN- $\gamma$ upregulates TNF- $\alpha$ receptors in a number of cell types, perhaps enhancing the sensitivity of cells to TNF- $\alpha$ (Montaldo et al., 1994; Zhang et al., 1994; Bebo and Linthicum, 1995). These events may contribute to amplification of the effects of TNF- $\alpha$, leading to susceptibility of luteal cells to cytokines.

A wealth of information has accrued during the past decade regarding a role for nitric oxide as a potent mediator of cell death. Nitric oxide is an important effector molecule of macrophage-induced cytotoxicity and also has a role in cytotoxicity of some cytokine-treated cells. Nitric oxide production can be stimulated in target cells by IFN- $\gamma$ and 
TNF- $\gamma$ and is increased synergistically by combinations of these cytokines (Amber et al., 1988). Nitric oxide mediates interleukin $1 \beta$ (IL-1 $\beta$ )-induced cytotoxicity in rat ovaries (Ellman et al., 1993), and it has been postulated that nitric oxide arises in conjunction with the proinflammatory events associated with ovulation (Ben-Shlomo et al., 1994). The results of the present study do not support a role for nitric oxide in cytokine-induced cell death of bovine luteal cells. These results are in accord with those of Jo et al. (1995b), who found that cytokine-induced death of murine luteal cells was independent of nitric oxide. In contrast, Jo et al. (1995b) and Olson et al. (1996) found that nitric oxide, as measured by its stable metabolite, nitrite, is produced by cultured luteal cells, whereas production of nitric oxide by bovine luteal cells was not observed in the present study. Although the latter observations are consistent with the inability of the nitric oxide synthase inhibitor L-NMMA to inhibit cytokine-induced cell death, the results of studies in which nitrite production was observed may indicate a species or experimental difference in the ability of luteal cells to produce this free radical intermediate.

A novel finding of the present study was that IFN- $\alpha$ inhibited cytokine-induced cell death. The mechanism by which this occurred is not clear, but IFN- $\alpha$ protects some cell types from apoptosis by enhancing expression of antiapoptotic genes such as Bcl-2 (Jewell et al., 1994). This cytokine may also serve in an anti-inflammatory capacity in some situations; it can interrupt autocrine stimulation of IL$1 \beta$ production by mononuclear cells, and it induces shedding of the TNF- $\alpha$ receptor into blood (Tilg et al., 1995; Dinarello, 1997). Soluble TNF receptors may serve as natural antagonists of TNF- $\alpha$ action and may be the mechanism by which IFN- $\alpha$ prevents TNF- $\alpha$ action in luteal cells. Further studies are necessary to evaluate this mechanism. In addition, IFN- $\alpha$ has other effects on cultured bovine luteal cells; in the presence of high concentrations of progesterone, this cytokine suppresses IFN- $\boldsymbol{\gamma}$-stimulated MHC class II molecule expression and TNF- $\alpha$-stimulated prostaglandin production (Benyo and Pate, 1992; Pate, 1995). IFN- $\alpha$, in low concentrations, also has mild stimulatory effects on progesterone production, whereas high concentrations inhibit progesterone production (Luck et al., 1992). It is not currently known whether IFN- $\alpha$ is produced within the corpus luteum of any species, but these findings indicate that IFN- $\alpha$, if present, may have important paracrine actions in relation to the survival of the corpus luteum.

In conclusion, the results of the present experiments increase our understanding of the intracellular effectors of proposed mediators of luteal cell death. It has been demonstrated that TNF- $\alpha$ and IFN- $\gamma$ induce DNA fragmentation in bovine luteal cells. The cytotoxic actions of TNF- $\alpha$ and IFN- $\gamma$ do not appear to be mediated by nitric oxide or arachidonic acid metabolism; in contrast, it appears that reactive oxygen species are at least partially responsible for cytokine-induced cell death in vitro. In addition, it is possible that IFN- $\alpha$ may confer a protective effect, preventing many of the actions of TNF- $\alpha$ and IFN- $\gamma$ on luteal cells.

Salaries and research support were provided by State and Federal funds appropriated to the Ohio Agricultural Research and Development Center, Ohio State University.

\section{References}

Amber IJ, Hibbs JB, Jr, Taintor RR and Vavrin Z (1988) Cytokines induce an L-arginine-dependent effector system in nonmacrophage cells Journal of Leukocyte Biology $4 \mathbf{4}$ 58-65

Aten RF, Duarte KM and Behrman HR (1992) Regulation of ovarian antioxidant vitamins, reduced glutathione, and lipid peroxidation by luteinizing hormone and prostaglandin $\mathrm{F}_{2 \alpha}$ Biology of Reproduction 46 401-407

Bagavandoss P, Wiggins RC, Kunkel SL, Remich DG and Keyes PL (1990) Tumor necrosis factor production and accumulation of inflammatory cells in the corpus luteum of pseudopregnancy and pregnancy in rabbits Biology of Reproduction 42 367-376

Bartoli F, Lin HK, Ghomashchi F, Gelb MH, Jain MK and Apitz-Castro R (1994) Tight binding inhibitors of 85-kDa phospholipase $A_{2}$ but not 14kDa phospholipase $A_{2}$ inhibit release of free arachidonate in thrombinstimulated human platelets Journal of Biological Chemistry 269 15625-15630

Bebo BF, Jr and Linthicum DS (1995) Expression of mRNA for 55-kDa and $75-\mathrm{kDa}$ tumor necrosis factor (TNF) receptors in mouse cerebrovascular endothelium: effects of interleukin-1 $\beta$, interferon- $\gamma$ and TNF- $\alpha$ on cultured cells Journal of Neuroimmunology 62 161-167

Ben-Shlomo I, Kokia E, Jackson MJ, Adashi EY and Payne DW (1994) Interleukin-1 stimulates nitrite production in the rat ovary: evidence for heterologous cell-cell interactions and for insulin-mediated regulation of the inducible isoform of nitric oxide synthase Biology of Reproduction $51310-318$

Benyo DF and JL Pate (1992) Tumor necrosis factor- $\alpha$ alters bovine luteal cell synthetic capacity and viability Endocrinology 130 854-860

Blair RM, Saatman R, Liou SS, Fortune JE and Hansel W (1997) Roles of leukotrienes in bovine corpus luteum regression: an in vivo microdialysis study Proceedings of the Society of Experimental Biology and Medicine 216 72-80

Dinarello CA (1997) Induction of interleukin-1 and interleukin-1 receptor antagonist Seminars in Oncology 24 (Supplement 9) S9-81-S9-83

Ellman C, Corbett JA, Misko TP, McDaniel M and Becherman KP (1993) Nitric oxide mediates interleukin-1-induced cellular cytotoxicity in the rat ovary Journal of Clinical Investigation 92 3053-3056

Endo T, Aten RF, Wang F and Behrman HR (1993) Coordinate induction and activation of metalloproteinase and ascorbate depletion in structural luteolysis Endocrinology 133 690-698

Fairchild DL and JL Pate (1991) Modulation of bovine luteal cell synthetic capacity by interferon- $\gamma$ Biology of Reproduction 44 357-363

Green LC, Wagner DA, Glogowski J, Skipper PL, Wishnok JS and Tannenbaum SR (1982) Analysis of nitrate, nitrite, and $\left[{ }^{15} \mathrm{~N}\right]$ nitrate in biological fluids Analytical Biochemistry 126 131-138

Green MH, Lowe JE, Delaney CA and Green IC (1996) Comet assay to detect nitric oxide-dependent DNA damage in mammalian cells Methods in Enzymology $269243-266$

Hansel W, Alila HW, Dowd JP and Milvae RA (1991) Differential origin and control mechanisms in small and large bovine luteal cells Journal of Reproduction and Fertility Supplement 43 77-89

Hehnke KE, Christenson LK, Ford SP and Taylor M (1994) Macrophage infiltration into the porcine corpus luteum during prostaglandin $F_{2 \alpha^{-}}$ induced luteolysis Biology of Reproduction 50 10-15

Heller RA and Kronke M (1994) Tumor necrosis factor receptor-mediated signaling pathways Journal of Cell Biology 126 5-9

Jewell AP, Worman CP, Lydyard PM, Yong KL, Giles FJ and Goldstone AH (1994) Interferon-alpha up-regulates bcl-2 expression and protects BCLL cells from apoptosis in vitro and in vivo. British Journal of Haematology 88 268-274 
Ji I, Slaughter RG, Ellis JA, Ji TH and Murdoch WJ (1991) Analyses of ovine corpora lutea for tumor necrosis factor mRNA and bioactivity during prostaglandin-induced luteolysis Molecular and Cellular Endocrinology $8177-80$

Jo T, Tomiyama T, Ohashi K et al. (1995a) Apoptosis of cultured mouse luteal cells induced by tumor necrosis factor-alpha and interferongamma Anatomical Record 241 70-76

Jo T, Terada N, Takauchi Y, Saji F, Nishizawa Y, Tanaka S and Kosaka H (1995b) Cytotoxic actions of cytokines on cultured mouse luteal cells are independent of nitric oxide Journal of Steroid Biochemistry and Molecular Biology 55 291-296

Kettelhut IC, Fiers W and Goldberg AL (1987) The toxic effects of tumor necrosis factor in vivo and their prevention by cyclooxygenase inhibitors Proceedings National Academy of Sciences USA $\mathbf{8 4}$ 4273-4277

Luck MR, Shale JA and Payne JH (1992) Direct stimulation of bovine ovarian progesterone secretion by low concentrations of alphainterferon Journal of Endocrinology 135 R5-R8

Matthews N, Neale ML, Jackson SK and Stark JM (1987) Tumor cell killing by tumor necrosis factor: inhibition by anaerobic conditions, free-radical scavengers and inhibitors of arachidonate metabolism Immunology 62 153-155

Montaldo PG, Carbone R, Corrias MV, Ferraris PC and Ponzoni M (1994) Synergistic differentiation-promoting activity of interferon gamma and tumor necrosis factor-alpha: role of receptor regulation on human neuroblasts Journal of the National Cancer Institute 86 1694-1701

Musicki B, Kodaman PH, Aten RF and Behrman HR (1996) Endocrine regulation of ascorbic acid transport and secretion in luteal cells Biology of Reproduction 54 399-406

Neale ML, Riera RA and Matthew N (1988) Involvement of phospholipase $\mathrm{A}_{2}$ activation in tumor cell killing by tumor necrosis factor Immunology 64 81-85

Nothnick WB and Pate JL (1990) Interleukin-1 $\beta$ is a potent stimulator of prostaglandin synthesis in bovine luteal cells Biology of Reproduction 43 898-903

Olson LM, Jones-Burton CM and Jablonka-Shariff A (1996) Nitric oxide decreases estradiol synthesis of rat luteinized ovarian cells: possible role for nitric oxide in functional luteal regression Endocrinology 137 3531-3539

Pate JL (1995) Involvement of immune cells in regulation of ovarian function Journal of Reproduction and Fertility Supplement 49 365-377

Pate JL and Condon WA (1982) Effects of serum and lipoproteins on steroidogenesis in cultured bovine luteal cells Molecular and Cellular Endocrinology 28 551-562

Pate JL and Condon WA (1984) Effects of prostaglandin $F_{2 \alpha}$ on agonistinduced progesterone production in cultured bovine luteal cells Biology of Reproduction 31 427-435

Pate JL and Townson (1994) Novel local regulators in luteal regression Journal of Animal Science 72 (Supplement 3) 31-42

Petroff BK, Ciereszko RE, Dabrowski K, Ottobre AC, Pope WF and Ottobre JS (1998) Depletion of vitamin C from pig corpora lutea by prostaglandin $\mathrm{F}_{2 \alpha}$-induced secretion of the vitamin Journal of Reproduction and Fertility 112 243-247

Petroff MG, Petroff BK and Pate JL (1999) Expression of cytokine messenger ribonucleic acids in the bovine corpus luteum Endocrinology 140 1018-1021

Rabinovitch A, Baquerizo H and Sumoski W (1990) Cytotoxic effects of cytokines on islet $\beta$-cells: evidence for involvement of eicosanoids Endocrinology 126 67-71

Rabinovitch A, Suarez WL, Thomas PD, Strynadka K and Simpson (1992) Cytotoxic effects of cytokines on rat islets: evidence for involvement of free radicals and lipid peroxidation Diabetologia 35 409-413

Rapoport R, Sklan D, Wolfenson D, Shaham-Albalancy A and Hanukoglu
(1998) Antioxidant capacity is correlated with steroidogenic status of the corpus luteum during the bovine estrous cycle Biochimica et Biophysica Acta 1380 133-140

Rueda BR, Tilly KI, Hansen TR, Hoyer PB and Tilly JL (1995) Expression of superoxide dismutase, catalase and glutathione peroxidase in the bovine corpus luteum: evidence supporting a role for oxidative stress in luteolysis Endocrine 3 227-232

Sawada M and Carlson JC (1991) Rapid plasma membrane changes in superoxide radical formation, fluidity, and phospholipase $A_{2}$ activity in the corpus luteum of the rat during induction of luteolysis Endocrinology 128 2992-2998

Schulze-Osthoff K, Bakker AC, Vanhaesebroeck B, Beyaert R, Jacob WA and Fiers W (1992) Cytotoxic activity of tumor necrosis factor is mediated by early damage of mitochondrial functions: evidence for the involvement of mitochondrial radical generation Journal of Biological Chemistry 267 5317-5323

Spanel-Borowski K, Rahner P and Ricken AM (1997) Immunolocalization of CD18-positive cells in the bovine ovary Journal of Reproduction and Fertility 111 197-205

Stuehr DJ and Marletta MA (1987) Synthesis of nitrite and nitrate in murine macrophage cell lines Cancer Research 47 5590-5594

Suffys P, Beyaert R, De Valck D, Vanhaesebroeck B, Van Roy F and Fiers W (1991) Tumor-necrosis-factor-mediated cytotoxicity is correlated with phospholipase- $\mathrm{A}_{2}$ activity, but not with arachidonic acid release per se. European Journal of Biochemistry 195 465-475

Sugino N, Telleria CM and Gibori G (1998a) Differential regulation of copper-zinc superoxide dismutase and manganese superoxide dismutase in the rat corpus luteum: induction of manganese superoxide dismutase messenger ribonucleic acid by inflammatory cytokines Biology of Reproduction 59 208-215

Sugino N, Hirosawa-Takamori M, Zhong L, Telleria CM, Shiota K and Gibori G (1998b) Hormonal regulation of copper-zinc superoxide dismutase and manganese superoxide dismutase messenger ribonucleic acid in the rat corpus luteum: induction by prolactin and placental lactogens Biology of Reproduction 59 599-605

Tilg H, Vogel W and Dinarello CA (1995) Interferon- $\alpha$ induces circulating tumor necrosis factor receptor p55 in humans Blood 85 433-435

Townson DH, Warren JS, Flory CM, Naftalin DM and Keyes PL (1996) Expression of monocyte chemoattractant protein-1 in the corpus luteum of the rat Biology of Reproduction 54 513-520

Tsai SJ and Wiltbank MC (1998) Prostaglandin $F_{2 \alpha}$ regulates distinct physiological changes in early and mid-cycle bovine corpora lutea Biology of Reproduction 58 346-352

Wiltbank MC, Guthrie PB, Mattson MP, Kater SB and Niswender GD (1989) Hormonal regulation of free intracellular calcium concentrations in small and large ovine luteal cells Biology of Reproduction 41 771-778

Wong GH and Goeddel DV (1988) Induction of manganous superoxide dismutase by tumor necrosis factor: possible protective mechanism Science 242 941-944

Wong GHW, Elwell JH, Oberley LW and Goeddel DV (1989) Manganous superoxide dismutase is essential for cellular resistance to cytotoxicity of tumor necrosis factor Cell 58 923-931

Zhang F, zur Hausen A, Hoffmann R, Grewe M and Decker K (1994) Rat liver macrophages express the $55 \mathrm{kDa}$ tumor necrosis factor receptor: modulation by interferon-gamma, lipopolysaccharide and tumor necrosis factor-alpha Biological Chemistry Hoppe-Seyler 375 249-254

Received 24 May 2000.

First decision 8 September 2000.

Revised manuscript received 11 December 2000.

Accepted 22 January 2001. 